原著

$$
\begin{gathered}
\text { 分子マーカーを用いた血小板アフェレーシスに } \\
\text { 拈ける止血機能動態の分析 }
\end{gathered}
$$

$\begin{array}{lll}\text { 照屋 } & \text { 純 梅嶋 朱美 } & \text { 鶴岡由美子 } \\ \text { 帝京大学市原病院輸血部, 第 } 3 \text { 内科 } \\ \text { 風間 } \\ \text { 睦美 } \quad \text { 林岡真知子 杉山 美雪 } \\ \text { 鎌倉 } \\ \text { 正英 安部 英 } \\ \text { 帝京大学輸血部, 第 } 1 \text { 内科 }\end{array}$

（昭和61年11月29日受付）

\title{
CHANGES OF HEMOSTATIC MOLECULAR MARKERS DURING DONOR PLATELETPHERESES USING CELL SEPARATORS
}

Jun Teruya, Akemi Umejima, Yumiko Tsuruoka, Mutsuyoshi Kazama*, Machiko Morioka*, Miyuki Sugiyama*, Masahide Kamakura* and Takeshi Abe*

Third Division, Department of Medicine and Blood Transfusion Serivice, Teikyo University

School of Medicine, Ichihara Hospital

*First Division, Department of Medicine and Blood Transfusion Serivice, Teikyo University School of Medicine

The changes of hemostatic molecular markers such as beta-thromboglobulin, platelet factor 4, fibrinopeptide A, soluble fibrin monomer complex, fibrinopeptide B beta 15-42, fibrin degradation product and fibrinogen are measured during donor plateltphereses using cell separators. They are most sensitive markers of platelet, coagulation system, and fibrinolysis. Plateletphereses were performed using Phenwall CS3000 in 13 cases and IBM2997 in 8 cases. Platelet and coagulation system were activated during plateletpheresis, although any side effect was not recognized. From the results we perform that processed volume of whole blood should be limited 2,000 ml, approximately half of ordinary apheresis, in cases of donors from the age of 45 to 54 . In addition donors who are considered to have any risk factor for thrombosis also should be omitted for plateletpheresis.

\section{I.はじめに}

セルセパレータを用いる血小板アフェレーシス の施行前後の供血者の凝固線溶因子並びに血小板 なぞの变化がこれまでに多数報告されているが， それらによれば血液学的な安全性は確立されたか のように見兄る。最近生体内の止血機能の分析法 として, 血小板, 凝固, 線維素溶解系の活動中に 形成される代謝産物を測定することが行われるよ らになった。血中に微量に存在するこれらの物質 は凝血学的分子マーカー（以下分子マーカー）と 総称され, 血中の血小板数や凝固線溶因子レベル より遥かに敏感にそれらの活性化, 代謝状態を反
映する，われわれは種々の疾患に扔いて分子マー カーを測定し，止血機能の動態を適格に判定する ことを試みてきた，今回セルセパレータによる血 小板アフェレーシスに際して, 分子マーカーの動 態を追跡しこの面からアフェレーシスの安全性を 検討した。

\section{II. 方 法}

1）血小板アフェレーシス：供血者は計21名で 男 18 名，女 3 名で平均年齢は 30.5 歳であった。 ルセパレータは13例はCS3000を用い，8例は IBM2997を用いた。 ブラッドアクセスは両側の时 静脈より, outletはアーガイルのメヂカットカ 
テーテルの16ゲージの側孔付き, inlet は同18ゲー ジを用いた。採血流量は, $40 \sim 50 \mathrm{ml} / \mathrm{min}$, 抗凝固 剂はACD-A 液を用い，その全血との比は， CS3000では 1：11〜13, IBM2997では 1：9〜10 とし，全血処理量は $4,000 \mathrm{~m} l$ を目標とし， $4.8 \pm$ $1.2 \times 10^{11}$ の血小板を得た（表 1 ）.

2) 血液検体は施行前, 全血 $1,000 \mathrm{~m} l$ 処理時, 終 了直後の 3 点, 体外循環回路の outlet で採血し た. 採血には，測定目的に従って以下に述べる抗 凝固剂を予め入れた $5 \mathrm{~m} l$ のプラスチックシリン ジを用い，血液をプラスチックシリンジに静かに 吸引したあと，直ちに泡立たないように注意して 約 10 回転倒混和を行い, $2,000 \times \mathrm{G}, 30$ 分間, $4{ }^{\circ} \mathrm{C}$ で冷却遠心して血浆分離をした。検体は全て検査 時点までー $20^{\circ} \mathrm{C}$ に保存した。

3）抗凝固剤（表 2)

(1) フィブリノペプチド A (FPA)，フィブリノ ペプチド $\mathrm{B} \beta_{15-42}(\mathrm{~B} \beta)$ 測定用：最終濃度としてク エン酸ソーダ $0.11 \mathrm{M}$, ヘパリン $1,000 \mathrm{U} / \mathrm{m} l$, アプ ロチニン $1 \mathrm{TIU} / \mathrm{m} l$ および $\mathrm{NaN}_{3} \quad 0.1 \%$ を含む溶 液. 本抗凝固剂 $0.5 \mathrm{~m} l$ に全血 $4.5 \mathrm{~m} l$ を混和した。

表 1 Procedure for Plateletpheresis

$\begin{array}{ll}\text { Cell Separator; } & \text { CS3000 in } 13 \text { cases } \\ & \text { IBM2997 in } 8 \text { cases } \\ \text { Blood Access; } & \text { Cubital Veins } \\ & \text { Using Argyll Medicat Catheter } \\ & 16 \mathrm{G} \text { for the Outlet } \\ & 18 \mathrm{G} \text { for the Inlet }\end{array}$

Processing Rate; $40 \sim 50 \mathrm{ml} / \mathrm{min}$

ACD-A Flow Ratio ; $1: 9 \sim 1: 12$

Total Blood Processed ; $4,000 \mathrm{ml}$

Platelet Yield ; $4.8 \pm 1.2 \times 10^{11}$ Platelets

Samples Drawn; 1. Before

2. After $1,000 \mathrm{~m} l$ Processed

3. After $4,000 \mathrm{~m} l$ Processed
(2) $\beta$-トロンボグロブリン( $\beta \mathrm{TG})$, platelet factor 4 (PF4) 測定用 : 最終濃度として, EDTA 55 $\mathrm{mg} / \mathrm{m} l$ およびテオフィリン $3 \mathrm{mg} / \mathrm{m} l$ を含む溶 液。本抗凝固剤 $0.3 \mathrm{ml}$ に全血 $4.7 \mathrm{~m} l$ を混和した。

(3) 可溶性フィブリンモノマー複合体 (SFMC), fibrin degradation product (FDP) 測 定用： $3.8 \%$ クエン酸ソーダ 1 容に全血 9 容を混

\section{Changes of $B-T G$ during Plateletpheresis}

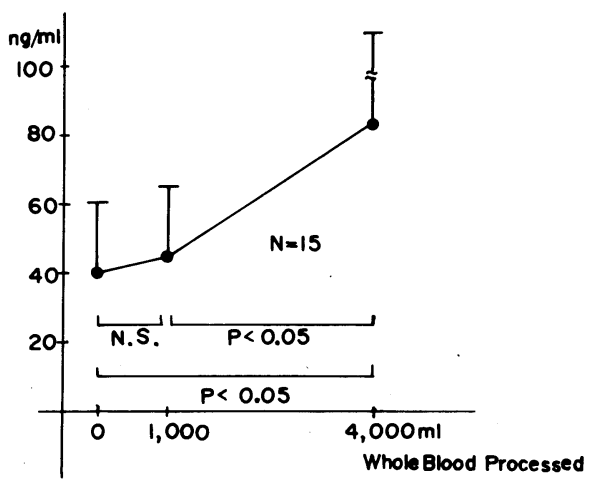

Changes of PF4 during Plateletpheresis

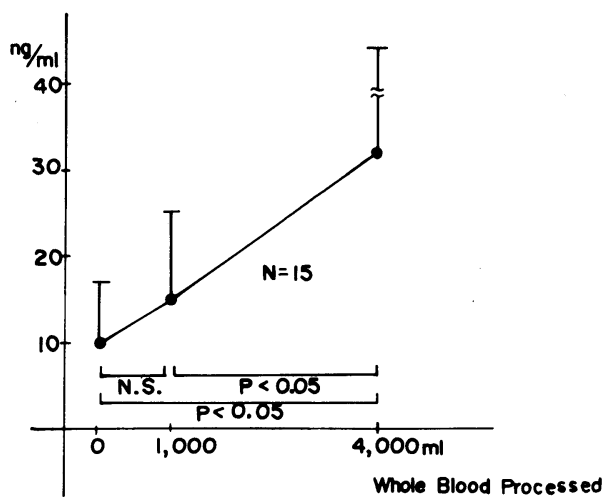

図 1

表 2 Assay methods for molecular markers

\begin{tabular}{l|l|l}
\hline & \multicolumn{1}{|c|}{ Methods } & \multicolumn{1}{c}{ Anticoagulants } \\
\hline 1. $\beta$-TG & $\beta$-TG Riapack (Amersham) & EDTA, Theophylline \\
2. PF4 & PF4 Ria Kit (Dynabot) & EDTA, Theophylline \\
3. FPA & Asserachrom FPA (Behringer-Mannheim) & Citrate Na, Heparin, Aprotinin \\
4. SFMC & FM Test (Behringer-Mannheim) & Citrate Na \\
5. B $\beta$ & B $\beta$ Ria Kit (IMCO) & Citrate Na, Heparin, Aprotinin \\
6. FDP & FDP-L (Teikoku-zoki) & Citrate Na \\
\hline
\end{tabular}


和した。

(4) 測定法：表 2 のよ5に各キットを用いて測 定した。

\section{III. 結 果}

1. $\beta \mathrm{TG}$ は開始前 $40.1 \pm 20.4 \mathrm{ng} / \mathrm{m} l$ から全血 $1,000 \mathrm{~m} l$ 処理時点で $45.2 \pm 20.0 \mathrm{ng} / \mathrm{m} l$ に増加し, 血小板採取終了時には $84.7 \pm 77.4 \mathrm{ng} / \mathrm{m} l$ に有意 に増加した。同様に PF4は開始前10.3土7.8ng/ $\mathrm{m} l$ から $1,000 \mathrm{~m} l$ 処理時に $14.1 \pm 9.4 \mathrm{ng} / \mathrm{m} l$, 終了 時には $32.5 \pm 26.8 \mathrm{ng} / \mathrm{m} l$ へと有意に増加した（図 1 ).

2. FPA は開始前 $3.4 \pm 2.6 \mathrm{ng} / \mathrm{m} l$ から, 全血 $1,000 \mathrm{~m} l$ 処理時点で $6.4 \pm 7.8 \mathrm{ng} / \mathrm{m} l$, 終了時には $12.3 \pm 13.9 \mathrm{ng} / \mathrm{m} l$ へと有意に増加した. SFMC は

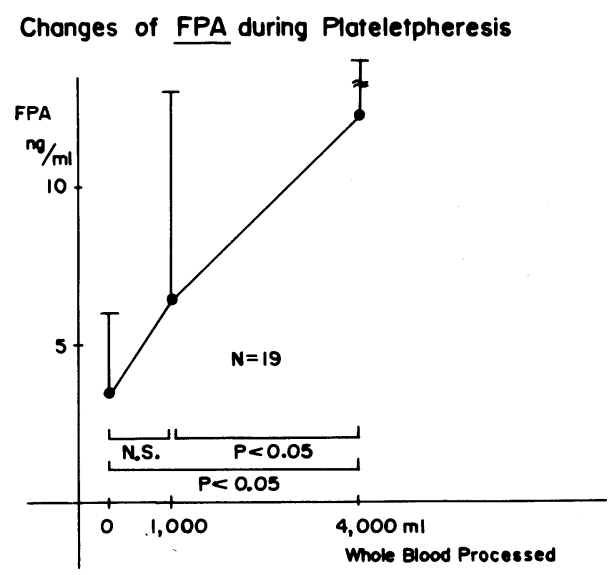

Changes of Fibrinogen during Plateletpheresis

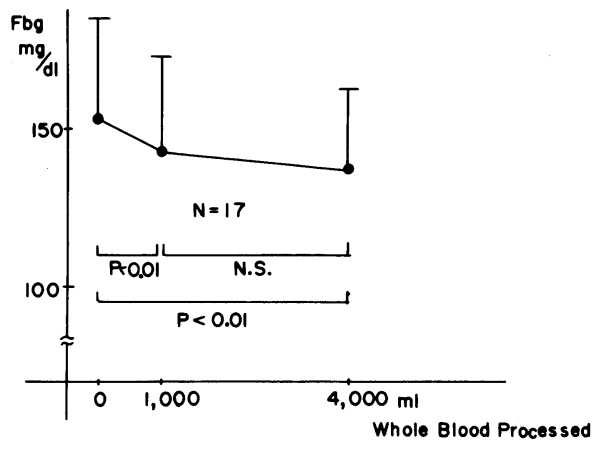

図 2
施行中 (一)であった。一方，フィブリノゲンは, 開始前 $152.8 \pm 34.0 \mathrm{mg} / \mathrm{d} l$, 全血 $1,000 \mathrm{~m} l$ 処理時

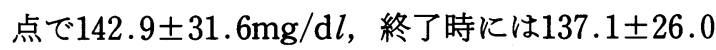
$\mathrm{mg} / \mathrm{d} l$ へと有意に低下した（図 2 ）.

3. $\mathrm{B} \beta$ は開始前 $15.0 \pm 13.9 \mathrm{ng} / \mathrm{m} l$, 全血 1,000 $\mathrm{m} l$ 処理時点で $13.1 \pm 11.4 \mathrm{ng} / \mathrm{m} l$, 終了時には $15.6 \pm 19.2 \mathrm{ng} / \mathrm{m} l$ と施行中有意な変動を示さな かった. 同様に FDP も施行中常に $10 \mu \mathrm{g} / \mathrm{m} l$ 以下 であった（図 3 ）。

4. 各分子マーカーの機種に因って分けた值を 表 3 に示した. 施行前, 施行後の各分子マーカー はCS3000とIBM2997との間に有意差が無かっ た。

4. 採取した濃厚血小板中の $\beta \mathrm{TG}$ とF4は

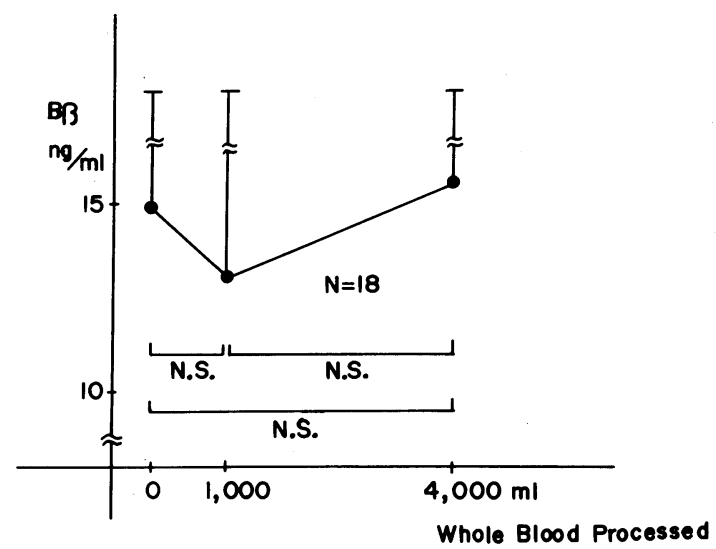

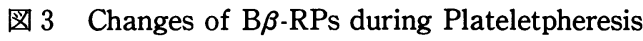

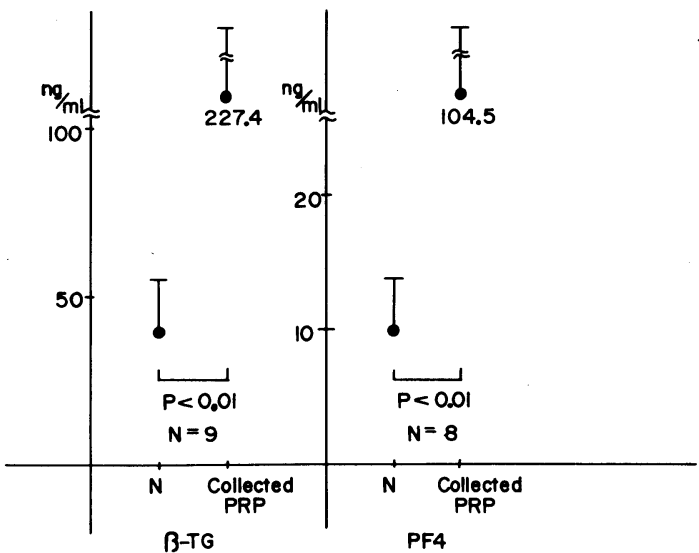

図 4 Differences of $\beta$-TG \& PF4 between Normal plasma and Collected PRP 
表 3 CS3000と IBM2997を用いたセルセパレータ施行中の分子マーカーの变動

\begin{tabular}{|c|c|c|c|c|c|c|c|}
\hline 分子マーカー & 全血処理量 $(\mathrm{m} l)$ & \multicolumn{3}{|l|}{ CS3000 } & \multicolumn{3}{|c|}{ IBM2997 } \\
\hline $\begin{array}{l}\beta \mathrm{TG} \\
\quad(\mathrm{ng} / \mathrm{m} l)\end{array}$ & $\begin{array}{r}0 \\
1,000 \\
4,000\end{array}$ & $\left.\begin{array}{c}41.3 \pm 18.9 \\
50.4 \pm 22.9 \\
100.9 \pm 106.9\end{array}\right]$ & $\mathrm{ns}$ & ns & $\begin{array}{l}41.9 \pm 23.5 \\
39.6 \pm 14.6 \\
64.2 \pm 31.1\end{array}$ & {$\left[\begin{array}{l}\mathrm{ns} \\
*\end{array}\right]$} & ns \\
\hline${ }^{\mathrm{PF} 4}(\mathrm{ng} / \mathrm{m} l)$ & $\begin{array}{r}0 \\
1,000 \\
4,000\end{array}$ & $\left.\begin{array}{l}11.2 \pm 8.1 \\
17.3 \pm 11.3 \\
35.4 \pm 40.3\end{array}\right]$ & $\begin{array}{l}\mathrm{ns} \\
\mathrm{ns}\end{array}$ & ns & $\begin{array}{l}10.0 \pm 7.7 \\
12.5 \pm 8.0 \\
30.1 \pm 24.0\end{array}$ & {$\left[\begin{array}{l}\mathrm{ns} \\
*\end{array}\right]$} & * \\
\hline $\begin{array}{l}\text { FPA } \\
\qquad(\mathrm{ng} / \mathrm{m} l)\end{array}$ & $\begin{array}{r}0 \\
1,000 \\
4,000\end{array}$ & $\left.\begin{array}{c}3.8 \pm 2.3 \\
9.3 \pm 9.0 \\
15.7 \pm 18.0\end{array}\right]$ & ns & $*$ & $\begin{array}{l}2.9 \pm 3.1 \\
2.3 \pm 2.7 \\
8.4 \pm 6.8\end{array}$ & ns & * \\
\hline $\begin{array}{c}\text { フィブリノゲン } \\
(\mathrm{mg} / \mathrm{d} l)\end{array}$ & $\begin{array}{r}0 \\
1,000 \\
4,000\end{array}$ & $\left.\begin{array}{l}144.9 \pm 36.7 \\
140.4 \pm 29.0 \\
126.4 \pm 26.0\end{array}\right]$ & $\begin{array}{l}\text { ns } \\
* *\end{array}$ & ** & $\begin{array}{l}153.6 \pm 39.4 \\
147.0 \pm 34.3 \\
145.8 \pm 24.8\end{array}$ & ns & ns \\
\hline${ }^{\mathrm{B} \beta}(\mathrm{ng} / \mathrm{m} l)$ & $\begin{array}{r}0 \\
1,000 \\
4,000\end{array}$ & $\left.\begin{array}{c}11.1 \pm 12.8 \\
10.2 \pm 6.6 \\
6.8 \pm 4.4\end{array}\right]$ & $\left.\begin{array}{l}\mathrm{ns} \\
\mathrm{ns}\end{array}\right]$ & ns & $\begin{array}{l}19.9 \pm 14.4 \\
16.7 \pm 15.3 \\
25.6 \pm 25.7\end{array}$ & {$\left[\begin{array}{l}\mathrm{ns} \\
\mathrm{ns}\end{array}\right]$} & ns \\
\hline
\end{tabular}

${ }^{*}: \mathrm{p}<0.05,{ }^{* *}: \mathrm{p}<0.01$, ns : not significant

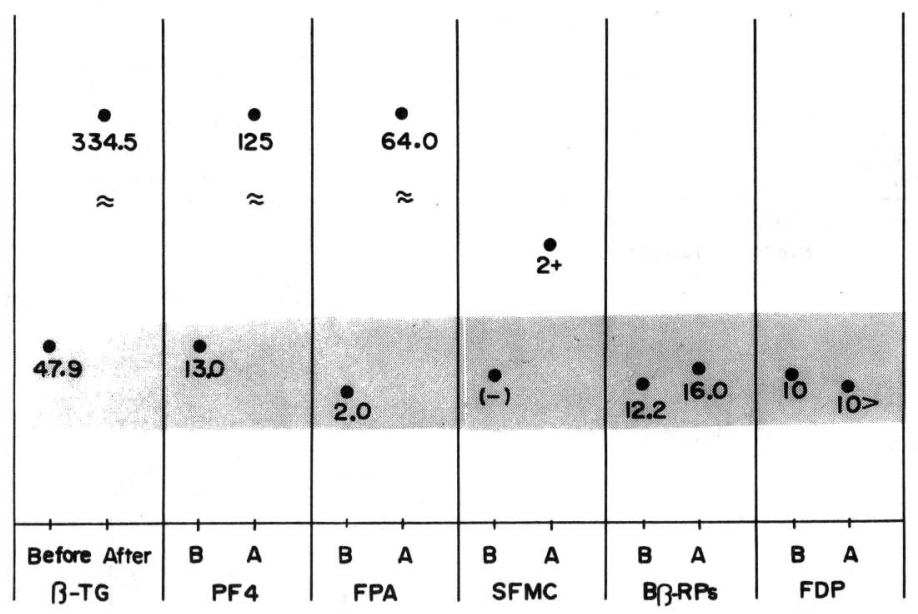

図 5. Changes of Molecular Markers Before \& After Plateletpheresis of a Donor with Difficulty in Blood Access

各々 $227.4 \pm 91.4 \mathrm{ng} / \mathrm{m} l, 104.5 \pm 32.0 \mathrm{ng} / \mathrm{m} l$ で あった（図 4 ).

一方, 日赤濃厚血小板中 $(\mathrm{n}=20)$ の $\beta \mathrm{TG}$ と PF4 は各々 $5,284.6 \pm 2,161.0 \mathrm{ng} / \mathrm{m} l, 2,173.9 \pm$ $1,863.1 \mathrm{ng} / \mathrm{m} l$ と高值を示した。
5. 図 5 は22歳男性供血者の例で, 血管が細いた めに常に上腕にマンシェットを巻いて，40６0 $\mathrm{mmHg}$ で駆血をすることにより，およそ $30 \mathrm{ml}$ min で血流を確保していた。しかし全血 $3,000 \mathrm{~m} l$ 処理後急に気分不快を訴えたために，その時点で 
血小板採取を終了した。 $\beta$ TGは，施行前47.9ng/ $\mathrm{m} l$ から中止時には $334.5 \mathrm{ng} / \mathrm{m} l, \mathrm{PF} 4$ も $13.0 \mathrm{ng} /$ $\mathrm{m} l$ から $125 \mathrm{ng} / \mathrm{m} l$ へと増加した. FPA は施行前 $2.0 \mathrm{ng} / \mathrm{m} l$ から $64.0 \mathrm{ng} / \mathrm{m} l$ へと増加し, SFMC \& (一) から $(2+)$ となった。一方, $\mathrm{B} \beta$ は $12.2 \mathrm{ng} /$ $\mathrm{m} l$ から $16.0 \mathrm{ng} / \mathrm{m} l$, FDP は $10 \mu \mathrm{g} / \mathrm{m} l$ から $10 \mu \mathrm{g} /$ $\mathrm{m} l$ 以下へといずれも正常範囲内での変動を示し たに過ぎなかった。

\section{IV. 考案}

生体中の止血機能の動態は, 従来活性化, 消耗 に基づく血小板数や凝固, 線維素溶解因子の減少 を指標として推定されるに過ぎなかった，近年， これらの活動によって形成される微量の代謝産物 の増加が，血小板や凝固，線維素溶解系の活性化 を鋭敏に反映するものとして，従来凝血学的には 困難であった凝固亢進状態の検出, 臨床的には血 栓症やDIC の診断に応用されるよらになった。こ れらの代謝産物は分子マーカーと総称され $3^{1) \sim 3)}$. 血中の血小板や凝固系, 線溶系の活性化 は，分子マーカーによって従来よりも鋭敏に検出 されると考えられる。

セルセパレータを用いた血小板アフェレーシス は最近多くの病院，血液センターなどで行われて いる。この血小板採取は供血者の安全性のために 厚生省による採血基準は通常の $200 \mathrm{~m} l, 400 \mathrm{~m} l$ 採 血や血浆採取よりも厳しくなっている，即ち，年 龄が $18 \sim 54$ 歳, 体重 $50 \mathrm{~kg}$ 以上, 血液比重 1.052 以上 あるいは血色素量 $12.5 \mathrm{~g} / \mathrm{d} l$ 以上, 血清総蛋白量 $6.1 \mathrm{~g} / \mathrm{d} l$ 以上, 血小板数 15 万 $/ \mu l$ 以上であり, 年間 実施回数は12回以内に限定されている4).

この血小板アフェレーシス施行中の主たる副作 用は vasovagal reflex(VVR)，あるいは多量のク エン酸ナトリウムの流入による低カルシウム血症 などに基づくものと考えられているが，施行中に VVRでは説明し得ない種々の心電図変化をみた といら報告もあり ${ }^{5)}$ ，供血者の安全性は必ずしも 完全に保証されている訳では無い。また，頻回の 血浆アフェレーシスでは, 低蛋白血症, 低アルブ ミン血症, 脂質代謝異常, アンチトロンビンIIIの 减少，血小板機能六進などを伴うことから動脈硬 化症や心筋梗塞あるいは血栓症を合併する危険性
が想定され，それらは通常の臨床検査では見逃さ れる可能性のあることが指摘されている6) 8).

一方，施行中の血液凝固因子，血小板数などの 変化に関する研究は多くなされて打り，殊に血小 板数とフィブリノゲンの低下などが報告されてい るが，何れも一過性のもので特に供血者に対して 重大な影響を及ぼすものでは無いとされてき た9).

然るに, アフェレーシス中供血者の血中 $\beta \mathrm{TG}$, PF4は全血処理量の増加に応じて直線的に増加 し, 終了時, 即ち全血 $4,000 \mathrm{~m} l$ 処理時には平均値 と共に標準偏差が増加した。フィブリノゲンは施 行中に有意に低下し，同時にFPAの増加が見ら れたため，それはモジュールへのフィブリノゲン 吸着だけではなく，凝固系が活性化されたことも 関与すると考えられた。この結果から血小板，凝 固系の活性化が血小板アフェレーシスの際に拈こ るが標準偏差が大きく，七ルセパレータによる血 小板, 凝固系の活性化は個人差が大きいといらこ とを示している。

セルセパレータの機種に因る差は表 3 に示した が，統計学的に有意差が無いものでも施行後には 増加する傾向にあり，2つの機種に因る差は無い ものと考えられた。

即ち，先に述べたよらな止血機能の指標として 極めて鋭敏な分子マーカーを用いて検討すると， 血小板アフェレーシス施行後には血小板，凝固系 が活性化され血栓症発症の 2 つの大きなリスク ファクターが増大したと判定された。それは血栓 症をおこしやすい疾患の 1 つである SLE 患者の 分子マーカーの值のプロフィルに近いものであ る.であるから一見正常と思われる集団の中から， 既に血栓症のリスクファクターをもっている供血 者を極力除外する必要がある. 即ち, セルセパレー タによるアフェレーシスに当たっては施行前から $\beta \mathrm{TG}, \mathrm{PF} 4, \mathrm{FPA}$ が高值である供血者の場合, さ らに血小板活性化，凝固六進が進んで血栓症を発 症する危険性のあることは否定できない。

このように供血者の血小板, 凝固系の活性化が おこっているが，採取した濃厚血小板中の $\beta \mathrm{TG,}$ PF4は中等度増加しているに過ぎず，日赤より供 
給される濃厚血小板中のそれらの $1 / 10$ 以下であっ た。であるから，少なくともセルセパレータにて 採取した濃厚血小板中の活性化血小板や凝固因子 が，受血者に与える影響は日赤濃厚血小板よりも 少ないと考えられた。赤濃厚血小板中で $\beta \mathrm{TG,}$ PF4がより高値であるのは, 血小板作成時の遠心 操作, 濃厚血小板の室温保存に於ける血小板の活 性化あるいは崩壊などが関与していると考えられ る。

図 5 に示したケースは血小板より $\beta \mathrm{TG}$ を精製 する目的でCS3000にて血小板アフェレ゙ーシスを 施行したボランティアである．施行前のスクリー ニングとしては通常の血算, プロトロンビン時間, GOT, GPT, TTT，ZTT，心電図，血清梅毒反 応, HBs 抗原の検査を行い, それらは全て正常で あった，血小板アフェレーシスを開始したが，血 管が細いため当初より採血流量不良のアラームが 屡々鳴り，その度に駆血や採血側の腕を暖めたり することにより，25～ $35 \mathrm{~m} l / \mathrm{min}$ の血流量で採取 を続けていた。 しかし全血 $3,000 \mathrm{~m} l$ 処理時点で急 に気分不快を訴えたため血小板採取を中止した。 その時の分子マーカーは $\beta \mathrm{TG}, \mathrm{PF} 4, \mathrm{FPA}$ が異常 高值を示し，凝固六進に対して比較的感度の低い SFMCでさえも 2 +であったことは極めて強い 血小板, 凝固系の活性化が扣こっていたことを示 唆するものである。この活性化は，採血困難によ り回路内の血流が中断したり, 屡々流量を変えざ るを得なかったことに関係していると思われた。

先に述べたように血小板採取は年秢制限などを 含めて最も厳しい基準があり，また各施設独自に スクリーニング項目を定めて，“健康な”供血者の 選択に努めている ${ }^{10)}$. 善意の正常供血者に対する 血小板アフェレーシスの施行中, あるいは施行後 でもそれに関係がある可能性のある事故は100\% 防止しなくてはならない。

血栓症は血小板あるいは凝固系の活性化に血流 や血管の要因が複雑に関係して発症すると考兄ら れて拈り, $\beta$ TG, FPA の臨界值を定めることは不 可能である。しかしながら，脳閉塞性血管障害の 患者では $\beta \mathrm{TG}$ が $100 \mathrm{ng} / \mathrm{m} l$ 以上, あるいは FPA が $20 \mathrm{ng} / \mathrm{m} l$ 以上に及ぶものがあり, 供血者として
はそれらの分子マーカーの前値が正常である者を 供血者として選択する必要があると思われる。

しかし，供血者が血栓症のリスクファクターを 有するか否かを，この様な分子マーカーの測定に よりスクリーニングすることは, 時間的並びに経 済的な要因からみて不可能である。それ故に，わ れわれは以下の点に注意してセルセパレータの安 全性を図っている。

(1) スクリーニングに拈いて心電図は必須のも のであるが，その心電図上少しでも虚血性変化が 疑われたり，狭心症の可能性のある胸痛などの既 往をもつ供血者は除外している。また，セルセパ レータ施行中は心電図モニターをしている。

(2) 脳閉塞性血管障害, 心筋梗塞などの血栓性疾 患のリスクが増える年齢を考慮して，対象年龄で ある18～54歳のらち45～54歳の供血者の全血処理 量を通常の約半分の $2,000 \mathrm{~m} l$ 以下に制限して実 施している。これは，血小板，凝固系が全血処理 量に比例して，すなわち時間と共に活性化が進ん でいくので，処理量を少なくすることにより活性 化の程度を低く抑えるのがその理由である。

(3) 血流確保が困難な例の場合は,殊に供血者の 状態に十分注意を払い，目標処理量まで到達しな くても長時間施行せずに中止することにしてい る.

\section{V. 結 語}

セルセパレータ IBM2997，CS3000を用いた血 小板アフェレーシスに際しての凝血学的分子マー カーの変動を検討した。

(1) 血小板アフェレーシス後には供血者の $\beta \mathrm{TG}, \mathrm{PF} 4, \mathrm{FPA}$ が増加, フィブリノゲンが低下 し, これは血小板, 凝固系の活性化を意味するも のと考えられた．その活性化の程度は 2 つの機種 間に差は無かった。

(2) 血小板アフェレーシスでは $\mathrm{B} \beta$ は変化せず, 線溶能の変化は認められなかった。

(3) セルセパレータにて採取した濃厚血小板中 の $\beta \mathrm{TG}, \mathrm{PF} 4$ は中等度増加していたが，日赤より 供給される濃厚血小板中のそれらよりも遙かに少 なく,受血者に対する影響は少ないと考えられた。 稿を終兄るにあたり，帝京大学病院中央検査部の島津千 
里氏, 並びに同輸血部の皆さんに深謝致します.

この論文の要旨は, 第34回日本輸血学会, 第 1 回 International Congress of the World Apheresis Association で 発表した.

\section{文献}

1) Wehrmacher, W.H.: Molecular markers of hemostasis : Introduction and overview. Seminars Thrombos Hemostas, 10(4) : 215-218, 1984.

2) Bick, R.L., Fared, J., Squillaci, G., Walenga, J., Bermes, E.W. and Messmore, H.L. : Molecular markers of hemostatic processes. (Abst) Fed. Proc., 42 : 1031, 1983.

3）風間睦美, 照屋 純, 中村一路, 森岡真知子, 安 部 英, 島津千里 : Molecular markerによる止 血機能のプロフィル診断. 厚生省特定疾患 血液 凝固異常症調查研究班昭和 60 年度研究報告書, pp. 189-196.

4）今井 勇 : 厚生省令. 官報第 17672 号, 昭和 61 年 1 月10日。

5) Komatsu, F. and Murohashi, I. : Bradycardia of donors during pheresis. (Abst) Frist International congress of the World Apheresis Association. p. 75, 1986.

6) Lundsgaard-Hansen, P.: Intensive plasmapheresis as a risk factor for arteriosclerotic cardiovascular disease? Vox Sang., $33: 1-4$, 1977.

7) Lundsgaard-Hansen, P.: Donor safety in plasmapheresis. Develop. Biol. Standard, 48: 287 $-295,1981$.

8）清水 勝：供血者の選択と保護. 成分輸血療法の 実際, 二之宮景光編, 南山堂, pp. 69-112, 1980.

9) Keller, A.J., Chirnside, A. and Urbaniak, S.J. : Coagulation abnormalities produced by plasma exchange on the cell separator with special reference to fibrinogen and platelet levels. Br. J. Haematol., $42:$ 593, 1979.

10）清水 勝：わが国におけるCytapheresisの現状 と供血者の安全対策について. 臨床血液, 19(10)： 1461-1466, 1978. 